\title{
Rice flour as a heat insulator for learning media for students with special needs
}

\section{DOI:10.36909/jer.ASSEEE.16119}

Rina Maryanti ${ }^{1}$, Asep Bayu Dani Nandiyanto ${ }^{2, *}$, Achmad Hufad ${ }^{1}$, S. Sunardi ${ }^{1}$, Deden Saepul Hidayat ${ }^{1}$

${ }^{1}$ Departemen Pendidikan Khusus, Universitas Pendidikan Indonesia, Bandung, Indonesia.

${ }^{2}$ Departemen Kimia, Universitas Pendidikan Indonesia, Bandung, Indonesia.

*Email: nandiyanto@upi.edu; Corresponding Author.

\begin{abstract}
The objective of this study was to determine the use of rice flour as a heat insulator for learning media for students with special needs. Experiments were done method by testing rice flour placed on the wall that heat radiated by bulb lamp with various intensities (i.e. 8 , 10 , and $12 \mathrm{~W}$ ). The results showed that rice flour is a good heat insulator. This is confirmed by the test results using thermocouple tools showing a decrease in temperature of the insulator testing toolbox. The rice flour caused the heat from the lamp inside the box to be restrained from spreading out completely. The concept of heat radiation and the change of heat adsorbed by rice flour was explained, which can be further developed for learning media for students with special needs. The results of this study are expected to facilitate teachers in providing understanding to students in understanding the occurrence of heat insulators, especially for students with special needs.
\end{abstract}

Keywords: Dimensions, Education, Heat transfer, Performance, Students with special needs. 


\section{INTRODUCTION}

A heat insulator is a material that inhibits the transfer of heat. Heat insulators are usually used in household appliances in cooking as heat separators. A good material for a heat insulator is a material that has a low thermal conductivity value. To meet the requirements in the application of lightweight brick as well as a heat insulator, the material must have a low thermal conductivity value, low density, having low compressive strength value (Syukur \& Kusumastuti, 2015). Learning about heat-insulating materials is very important. That is because we often find heat insulators and use them in daily life.

Various heat-insulating materials are available, which were used to reduce heat leakage and temperature dissipation (Soekoco, 2016). Some examples of heat-insulating materials are polyester and glass wool. The process of making heat-insulating fibers made from polyester is not environmentally friendly. This is because the polyester material is derived from petroleum. The process of making glass wool is also considered less environmentally friendly, this is because when manufacturing glass fiber requires relatively high energy to reach a temperature of $1500-1700^{\circ} \mathrm{C}$. Apart from that, if the heat-insulating materials are used as a learning medium, the teacher will find difficulties in getting the materials. This is especially facing if the teaching and learning process is done in a place with difficult access and transportation. Indeed, this will be found in Indonesia as a developing and archipelago country. In fact, understanding the concept of science material is important, especially for vocational schools that need experiments and relate to practicum (Rosina et al., 2021).

For students in general, they may easily understand what a heat insulator is. Unlike students with special needs, they need concrete media and simple explanations (Maryanti et al., 2021). Students with special needs have problems in both developmental and academic 
aspects. Thus, they have an impact on problems in the learning process. They need special education and services (Maryanti et al., 2021). Methods and media must be adapted for supporting the teaching and learning process for students with special needs. Objects or something that students often encounter in daily life can be used as learning media, especially for students with special needs.

Here, this study used rice flour as one of the alternative learning media used. Although many studies discussed heat insulators, until now, there has been no research discussing the use of Rice flour as a heat insulator for learning media in students with special needs. Rice flour is one of the materials that can be found in daily life. Its harmless properties make it possible for being learning media that can be used by children. The experiments were done by testing rice flour as an insulator, put on the wall, and radiated by a lamp with various intensities (by varying lamp energy of 8,10 , and $12 \mathrm{~W}$ ). We used a thermocouple analysis tool to determine the temperature changes that occur over a certain time duration. This was done to find out how much heat absorbs by rice flour which is used as an insulator.

\section{MATERIAL AND METHOD}

We focused this study on the use of rice flour as a heat insulator for learning media in students with special needs. Figure 1 describes the stages of the research procedure which includes the planning stage by preparing various tools and materials, the implementation stage by conducting experimental activities using rice flour as a heat insulator, and finally analyzing the experimental data by observing and analyzing the data obtained.
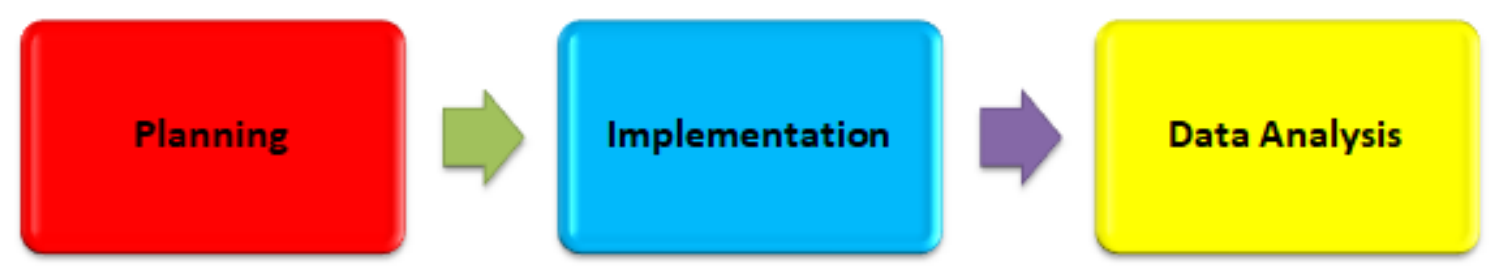
FIGURE 1 Research procedure

This study used experimental materials: rice flour (Rose Brand, PT Budi Makmur Perkasa, Indonesia) and water (AQUA, PT Tirta Investama, Indonesia). The tools used include 8, 10, and $12 \mathrm{~W}$ of light bulbs (Philips, PT Philips Indonesia, Indonesia), $250 \mathrm{~mL}$ of measuring cup, measure scales (Nankai, PT Rohartindo Nusantara Luas, Indonesia), spoon, stopwatch, digital thermocouple, and an insulator testing toolbox. The concept of heat transfer is adapted from our previous study (Nandiyanto et al., 2020) (Figure 2).

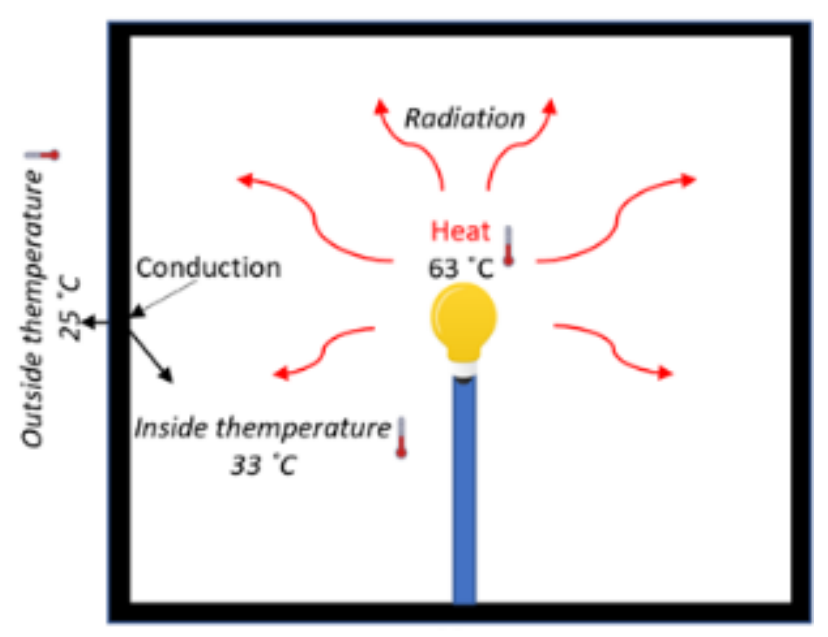

FIGURE 2 Illustration of the concept of the equipment used for heat radiation

We carried out the procedure for experimental activities, namely: (i) Weighing $200 \mathrm{~g}$ of Rice flour, (ii) adding $250 \mathrm{~mL}$ of water into a measuring cup, (iii) adding $200 \mathrm{~g}$ of Rice flour and $250 \mathrm{~mL}$ of water into the container and stirring until they distributed forming the dough, (iv) pasting the dough on the wall in the insulator testing toolbox (with the thickness of $5 \mathrm{~mm}$, measured by a ruler) and keep it until dry, (v) testing rice flour as an insulator using a light bulb $(8,10$, or $12 \mathrm{~W})$ in the box of the test apparatus, (vi) installing 4 thermocouples inside and 8 outside the box of the insulator testing apparatus (each side 3 thermocouples), (vii) calculating each thermocouple temperature change in the duration range $(0,5,10,15,20,25$, $30,35,40$, and 45 minutes) using a stopwatch and record the results. 
In short, the experimental demonstration was done by observing the heating phenomenon from the radiation of a bulb lamp (that is placed inside the cube) the walls (that were patched by Rice flour). The dimensions of the cube were $30 \times 30 \times 30 \mathrm{~cm}$ for length $\mathrm{x}$ width $\mathrm{x}$ height, respectively. This cube was designed so that the walls can be replaced with different materials and insulators with the same thickness and same area. A bulb lamp was employed to produce heat radiation inside the cube (at the center) with a single switch that was put in to make it easy to turn on/off the light. To test the heat transfer phenomena in the cube, several thermometers were put into several positions and the temperatures were measured every $5 \mathrm{~min}$. The inside of the cube was equipped with four thermometers (one of them is attached to the inner wall), whereas outside the cube was placed two thermometers to get information about the leakage of heat. The placed thermometers were used to determine the heat transfer by radiation as well as conduction heat transfer. The concept of conduction and heat loss was obtained by comparing the thermometers inside the cube and on the outer wall. All thermometers have specifications:

(i) $\quad$ Range temperature $=$ between -50 and $110^{\circ} \mathrm{C}$;

(ii) Temperature resolution $=0.1^{\circ} \mathrm{C}$;

(iii) Operating voltage $=1.5 \mathrm{~V}$;

(iv) Battery = LR44 Buttoned Batteries;

(v) Thermometer dimensions $=48 \times 28.6 \times 15.2 \mathrm{~mm}$;

(vi) Thermometer monitoring screen dimensions (LCD) $=46 \times 27 \mathrm{~mm}$.

To ensure the investigation of heat radiated from the bulb lamp, the thermometers were placed with the distance between them of $5 \mathrm{~cm}$ each. In addition, cloth tape was put between the attached walls to prevent air exchanges to the heating system. 


\section{RESULTS AND DISCUSSION}

Figure 3 shows the experimental apparatus used in this study. In short, the experiments were done by observing the change of temperature as a function of time as the effect of heat radiation of the bulb lamp, which was obtained from the change of temperature based on thermometers. The concept of the experiment is the heat transfer phenomena, observing using an insulator testing box made of iron (dimensions of 30x30x30 cm) where each side on all four sides is coated with Rice flour dough. On the the top side, a light bulb was inputted. The light bulb was placed in the center of the box for emitting heat. Thermocouple was used to measure the temperature on the four sides inside the box. On the outside, there are two thermocouples in each side to measure the temperature outside with a distance of 5 and 10 cm.

Figure 4 shows the concept display of the insulator testing experimental tool from above. The bulb lamp emitted heat radiation. Thus, temperature gauges (TA1, TB1, TC1, and TD1) are installed inside on each side. Each side (A, B, C, and D) was coated with Rice flour as an insulator. On each outside side, two temperature gauges are installed with a distance of $5 \mathrm{~cm}$ (TA2, TB2, TC2, and TD2) and $10 \mathrm{~cm}$ (TA3, TB3, TC3, and TD3). 


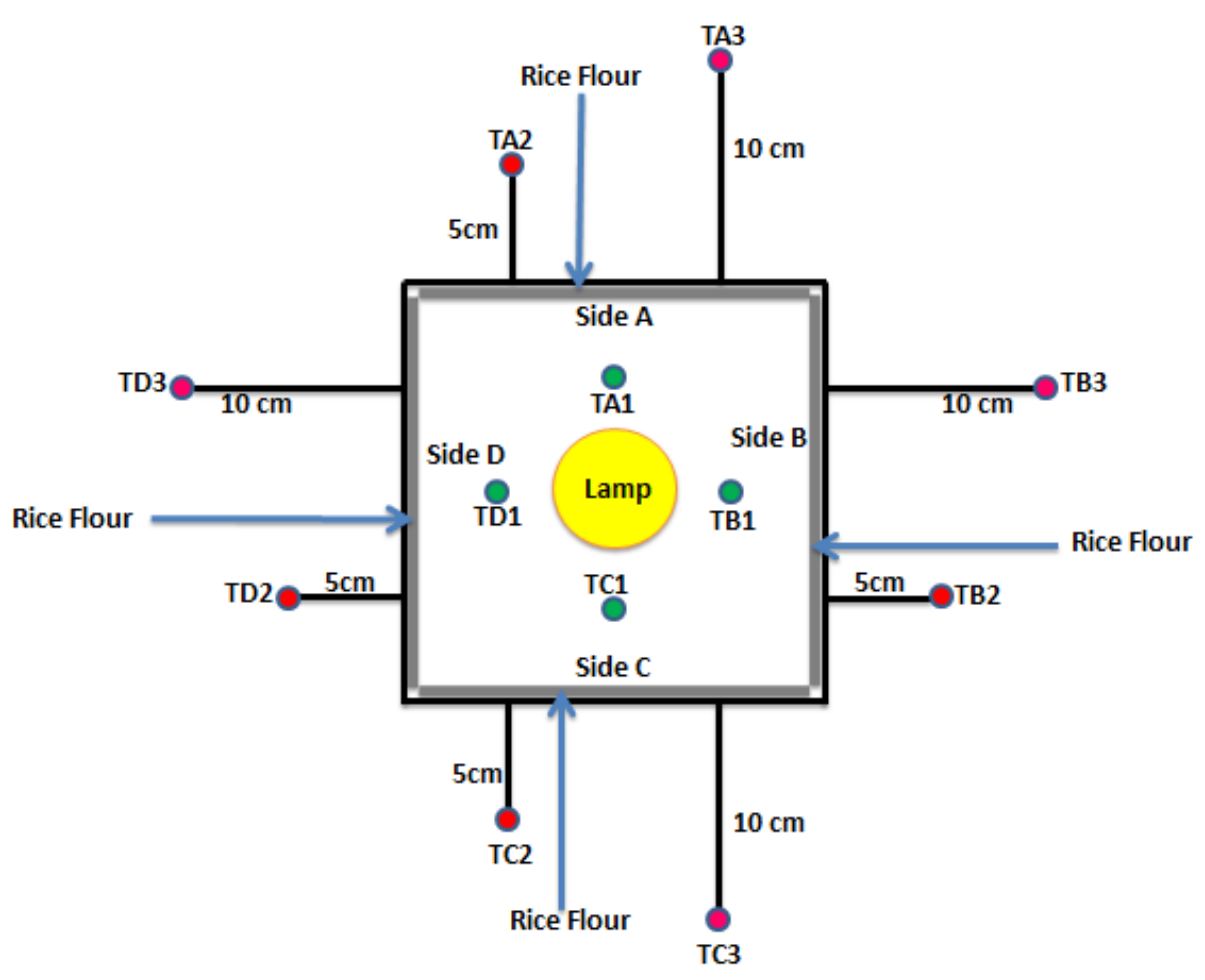

FIGURE 3 2D layout of the heat transfer toolbox (taken from top of the box)

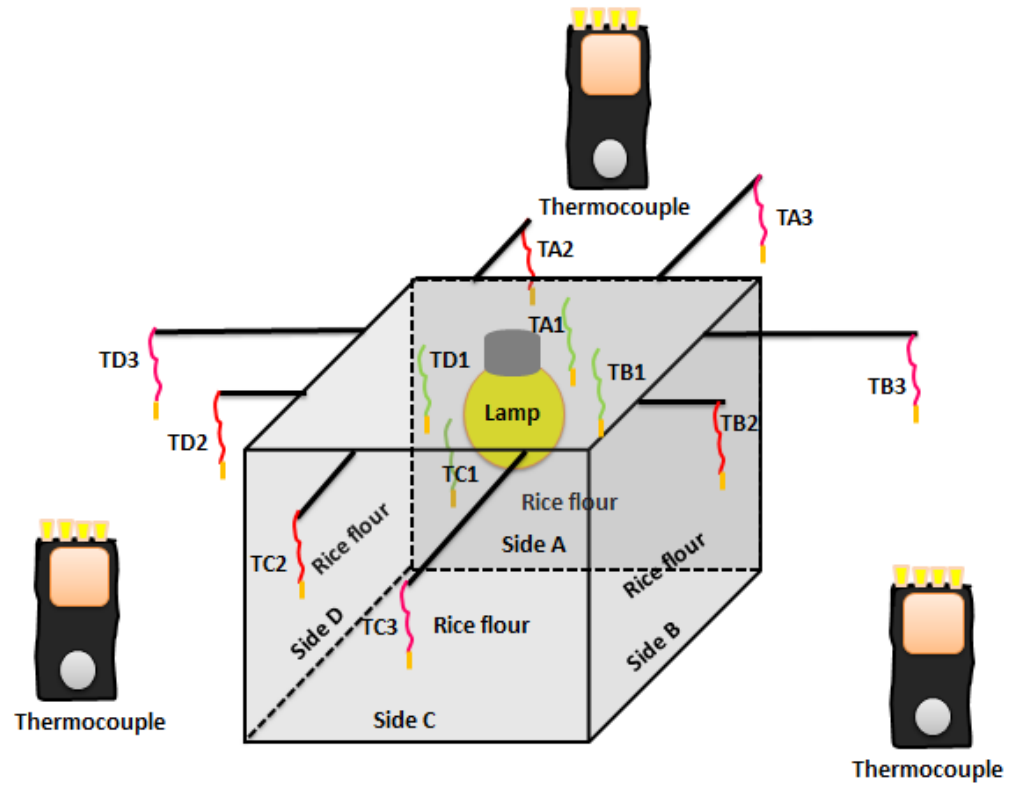

FIGURE 4 3D layout of the heat transfer toolbox

We conducted experimental trials using rice flour as an insulator and three variations of lamp power $(8,10$, and $12 \mathrm{~W})$. We used thermocouples to measure the temperature. Table 1 
describes the test results of rice flour as an insulator using an $8 \mathrm{~W}$ lamp power. We put 12 temperature test points, namely 4 points inside the insulator testing tool box (TA1, TB1, TC1, and TD1) and eight outside points with different distances of $5 \mathrm{~cm}$ (TA2, TB2, TC2, and TD2) and $10 \mathrm{~cm}$ ( TA3, TB3, TC3, and TD3). Data is explained in the following:

(i) The data from the analysis showed that the 4 points in the insulator testing tool box (TA1, TB1, TC1, and TD1) had the same temperature values at the beginning of the test at $28.20^{\circ} \mathrm{C}(0 \mathrm{~min})$ and at the end of the test $27.30^{\circ} \mathrm{C}(45 \mathrm{~min})$. The temperature in the toolbox was stable with an average temperature of $28.09^{\circ} \mathrm{C}$ during the 45 -min test.

(ii) The results of the analysis of 4 points outside the box of the insulator testing tool with a distance of $5 \mathrm{~cm}(\mathrm{TA} 2, \mathrm{~TB} 2, \mathrm{TC} 2$, and TD2) had the same temperature value at the beginning of the test of $25.60^{\circ} \mathrm{C}(0 \mathrm{~min})$ and at the end of the test of $24.80^{\circ} \mathrm{C}(45 \mathrm{~min})$. The temperature outside the test equipment box looks stable with an average temperature of $25.04^{\circ} \mathrm{C}$ during $45 \mathrm{~min}$ of testing.

(iii) The results of the analysis of 4 points outside the box of the insulator testing tool with a distance of $10 \mathrm{~cm}$ (TA3, TB3, TC3, and TD3) had the same temperature value at the beginning of the test at $25.50^{\circ} \mathrm{C}(0 \mathrm{~min})$ and at the end of the test $24.70^{\circ} \mathrm{C}(45 \mathrm{~min})$. The temperature outside of the test tool box looks stable with an average temperature of $24.78^{\circ} \mathrm{C}$ during the $45-$ min test.

The results of the temperature observations were in a good agreement with other side of the box. Detailed data for the temperature are shown in Tables 2 and 3. Then, the comparison data for the average temperature as a function of lamp power is shown in Table 4. 
Table 1 Testing Rice Flour using a 8-W lamp. $T_{a v e}$ is the average temperature.

\begin{tabular}{|l|c|c|c|c|c|c|c|c|c|c|c|}
\hline Sample & \multicolumn{9}{|c|}{ Temperature $\left({ }^{\circ} \mathbf{C}\right)$ at testing time (min) } \\
\cline { 2 - 15 } & $\mathbf{0}$ & $\mathbf{5}$ & $\mathbf{1 0}$ & $\mathbf{1 5}$ & $\mathbf{2 0}$ & $\mathbf{2 5}$ & $\mathbf{3 0}$ & $\mathbf{3 5}$ & $\mathbf{4 0}$ & $\mathbf{4 5}$ & $\boldsymbol{T}_{\text {ave }}$ \\
\hline TA1 & 28.20 & 28.90 & 28.20 & 29.80 & 30.20 & 28.20 & 27.20 & 27.00 & 25.90 & 27.30 & 28.09 \\
\hline TA2 & 25.60 & 25.40 & 25.50 & 24.30 & 26.20 & 25.20 & 24.20 & 24.50 & 24.70 & 24.80 & 25.04 \\
\hline TA3 & 25.50 & 25.20 & 25.30 & 23.30 & 25.90 & 25.20 & 24.00 & 24.30 & 24.40 & 24.70 & 24.78 \\
\hline TB1 & 28.20 & 28.90 & 28.20 & 29.80 & 30.20 & 28.20 & 27.20 & 27.00 & 25.90 & 27.30 & 28.09 \\
\hline TB2 & 25.60 & 25.40 & 25.50 & 24.30 & 26.20 & 25.20 & 24.20 & 24.50 & 24.70 & 24.80 & 25.04 \\
\hline TB3 & 25.50 & 25.20 & 25.30 & 23.30 & 25.90 & 25.20 & 24.00 & 24.30 & 24.40 & 24.70 & 24.78 \\
\hline TC1 & 28.20 & 28.90 & 28.20 & 29.80 & 30.20 & 28.20 & 27.20 & 27.00 & 25.90 & 27.30 & 28.09 \\
\hline TC2 & 25.60 & 25.40 & 25.50 & 24.30 & 26.20 & 25.20 & 24.20 & 24.50 & 24.70 & 24.80 & 25.04 \\
\hline TC3 & 25.50 & 25.20 & 25.30 & 23.30 & 25.90 & 25.20 & 24.00 & 24.30 & 24.40 & 24.70 & 24.78 \\
\hline TD1 & 28.20 & 28.90 & 28.20 & 29.80 & 30.20 & 28.20 & 27.20 & 27.00 & 25.90 & 27.30 & 28.09 \\
\hline TD2 & 25.60 & 25.40 & 25.50 & 24.30 & 26.20 & 25.20 & 24.20 & 24.50 & 24.70 & 24.80 & 25.04 \\
\hline TD3 & 25.50 & 25.20 & 25.30 & 23.30 & 25.90 & 25.20 & 24.00 & 24.30 & 24.40 & 24.70 & 24.78 \\
\hline
\end{tabular}

Table 2 Testing Rice Flour using a 10-W lamp. $T_{\text {ave }}$ is the average temperature.

\begin{tabular}{|l|c|c|c|c|c|c|c|c|c|c|c|}
\hline Sample & \multicolumn{9}{|c|}{ Temperature $\left({ }^{\circ} \mathbf{C}\right)$ at testing time (min) } \\
\cline { 2 - 14 } & $\mathbf{0}$ & $\mathbf{5}$ & $\mathbf{1 0}$ & $\mathbf{1 5}$ & $\mathbf{2 0}$ & $\mathbf{2 5}$ & $\mathbf{3 0}$ & $\mathbf{3 5}$ & $\mathbf{4 0}$ & $\mathbf{4 5}$ & $\boldsymbol{T}_{\text {ave }}$ \\
\hline TA1 & 28.40 & 29.30 & 27.30 & 17.70 & 28.10 & 27.80 & 28.00 & 27.90 & 28.00 & 28.00 & 27.05 \\
\hline TA2 & 24.70 & 25.10 & 25.00 & 25.30 & 25.60 & 25.20 & 25.20 & 25.30 & 25.20 & 25.20 & 25.18 \\
\hline TA3 & 24.50 & 24.80 & 24.80 & 25.30 & 25.40 & 25.00 & 25.00 & 25.00 & 25.00 & 25.10 & 24.99 \\
\hline TB1 & 28.40 & 29.30 & 27.30 & 17.70 & 28.10 & 27.80 & 28.00 & 27.90 & 28.00 & 28.00 & 27.05 \\
\hline TB2 & 24.70 & 25.10 & 25.00 & 25.30 & 25.60 & 25.20 & 25.20 & 25.30 & 25.20 & 25.20 & 25.18 \\
\hline TB3 & 24.50 & 24.80 & 24.80 & 25.30 & 25.40 & 25.00 & 25.00 & 25.00 & 25.00 & 25.10 & 24.99 \\
\hline TC1 & 28.40 & 29.30 & 27.30 & 17.70 & 28.10 & 27.80 & 28.00 & 27.90 & 28.00 & 28.00 & 27.05 \\
\hline TC2 & 24.70 & 25.10 & 25.00 & 25.30 & 25.60 & 25.20 & 25.20 & 25.30 & 25.20 & 25.20 & 25.18 \\
\hline TC3 & 24.50 & 24.80 & 24.80 & 25.30 & 25.40 & 25.00 & 25.00 & 25.00 & 25.00 & 25.10 & 24.99 \\
\hline TD1 & 28.40 & 29.30 & 27.30 & 17.70 & 28.10 & 27.80 & 28.00 & 27.90 & 28.00 & 28.00 & 27.05 \\
\hline TD2 & 24.70 & 25.10 & 25.00 & 25.30 & 25.60 & 25.20 & 25.20 & 25.30 & 25.20 & 25.20 & 25.18 \\
\hline TD3 & 24.50 & 24.80 & 24.80 & 25.30 & 25.40 & 25.00 & 25.00 & 25.00 & 25.00 & 25.10 & 24.99 \\
\hline
\end{tabular}


Table 3 Testing Rice Flour using a 12-W lamp. $T_{\text {ave }}$ is the average temperature.

\begin{tabular}{|l|c|c|c|c|c|c|c|c|c|c|c|}
\hline Sample & \multicolumn{9}{|c|}{ Temperature $\left({ }^{\circ} \mathbf{C}\right)$ at testing time (min) } \\
& $\mathbf{0}$ & $\mathbf{5}$ & $\mathbf{1 0}$ & $\mathbf{1 5}$ & $\mathbf{2 0}$ & $\mathbf{2 5}$ & $\mathbf{3 0}$ & $\mathbf{3 5}$ & $\mathbf{4 0}$ & $\mathbf{4 5}$ & $\boldsymbol{T}_{\text {ave }}$ \\
& & & & & & & & & & & \\
\hline TA1" & 27.90 & 28.10 & 28.00 & 28.20 & 28.10 & 27.70 & 28.40 & 28.50 & 28.40 & 28.60 & 28.19 \\
\hline TA2" & 25.10 & 25.30 & 25.70 & 25.40 & 25.40 & 24.90 & 25.10 & 25.20 & 24.90 & 25.20 & 25.22 \\
\hline TA3" & 25.10 & 25.20 & 25.70 & 25.30 & 25.30 & 24.60 & 25.00 & 24.90 & 24.80 & 25.10 & 22.57 \\
\hline TB1" & 27.90 & 28.10 & 28.00 & 28.20 & 28.10 & 27.70 & 28.40 & 28.50 & 28.40 & 28.60 & 28.19 \\
\hline TB2" & 25.10 & 25.30 & 25.70 & 25.40 & 25.40 & 24.90 & 25.10 & 25.20 & 24.90 & 25.20 & 25.22 \\
\hline TB3" & 25.10 & 25.20 & 25.70 & 25.30 & 25.30 & 24.60 & 25.00 & 24.90 & 24.80 & 25.10 & 22.57 \\
\hline TC1" & 27.90 & 28.10 & 28.00 & 28.20 & 28.10 & 27.70 & 28.40 & 28.50 & 28.40 & 28.60 & 28.19 \\
\hline TC2" & 25.10 & 25.30 & 25.70 & 25.40 & 25.40 & 24.90 & 25.10 & 25.20 & 24.90 & 25.20 & 25.22 \\
\hline TC3" & 25.10 & 25.20 & 25.70 & 25.30 & 25.30 & 24.60 & 25.00 & 24.90 & 24.80 & 25.10 & 22.57 \\
\hline TD1" & 27.90 & 28.10 & 28.00 & 28.20 & 28.10 & 27.70 & 28.40 & 28.50 & 28.40 & 28.60 & 28.19 \\
\hline TD2" & 25.10 & 25.30 & 25.70 & 25.40 & 25.40 & 24.90 & 25.10 & 25.20 & 24.90 & 25.20 & 25.22 \\
\hline TD3" & 25.10 & 25.20 & 25.70 & 25.30 & 25.30 & 24.60 & 25.00 & 24.90 & 24.80 & 25.10 & 22.57 \\
\hline
\end{tabular}

Table 4 Average temperature as the effect of lamp power. $T_{a v e}$ is the average temperature.

\begin{tabular}{|c|c|c|c|c|c|c|c|c|c|c|c|c|}
\hline \multirow{2}{*}{$\begin{array}{l}\text { Lamp } \\
\text { power }\end{array}$} & \multirow[t]{2}{*}{ Position } & \multicolumn{11}{|c|}{ Temperature $\left({ }^{\circ} \mathrm{C}\right)$ at testing time $(\mathrm{min})$} \\
\hline & & 0 & 5 & 10 & 15 & 20 & 25 & 30 & 35 & 40 & 45 & $T_{\text {ave }}$ \\
\hline \multirow{3}{*}{$8 \mathrm{~W}$} & Inside box & 28.20 & 28.90 & 28.20 & 29.80 & 30.20 & 28.20 & 27.20 & 27.00 & 25.90 & 27.30 & 28.09 \\
\hline & $\begin{array}{l}\text { Outside } \\
\text { box: } 5 \mathrm{~cm}\end{array}$ & 25.60 & 25.40 & 25.50 & 24.30 & 26.20 & 25.20 & 24.20 & 24.50 & 24.70 & 24.80 & 25.04 \\
\hline & $\begin{array}{l}\text { Outside } \\
\text { box: } 10 \mathrm{~cm}\end{array}$ & 25.50 & 25.20 & 25.30 & 23.30 & 25.90 & 25.20 & 24.00 & 24.30 & 24.40 & 24.70 & 24.78 \\
\hline \multirow{3}{*}{$10 \mathrm{~W}$} & Inside box & 28.40 & 29.30 & 27.30 & 17.70 & 28.10 & 27.80 & 28.00 & 27.90 & 28.00 & 28.00 & 27.05 \\
\hline & $\begin{array}{l}\text { Outside } \\
\text { box: } 5 \mathrm{~cm}\end{array}$ & 24.70 & 25.10 & 25.00 & 25.30 & 25.60 & 25.20 & 25.20 & 25.30 & 25.20 & 25.20 & 25.18 \\
\hline & $\begin{array}{l}\text { Outside } \\
\text { box: } 10 \mathrm{~cm}\end{array}$ & 24.50 & 24.80 & 24.80 & 25.30 & 25.40 & 25.00 & 25.00 & 25.00 & 25.00 & 25.10 & 24.99 \\
\hline \multirow{3}{*}{$12 \mathrm{~W}$} & Inside box & 27.90 & 28.10 & 28.00 & 28.20 & 28.10 & 27.70 & 28.40 & 28.50 & 28.40 & 28.60 & 28.19 \\
\hline & $\begin{array}{l}\text { Outside } \\
\text { box: } 5 \mathrm{~cm}\end{array}$ & 25.10 & 25.30 & 25.70 & 25.40 & 25.40 & 24.90 & 25.10 & 25.20 & 24.90 & 25.20 & 25.22 \\
\hline & $\begin{array}{l}\text { Outside } \\
\text { box: } 10 \mathrm{~cm}\end{array}$ & 25.10 & 25.20 & 25.70 & 25.30 & 25.30 & 24.60 & 25.00 & 24.90 & 24.80 & 25.10 & 22.57 \\
\hline
\end{tabular}

The results presented the difference in temperature inside and outside the box of the insulator testing tool. The average five test points from the initial time to 45 -min testing showed the increases in temperature. This is confirmed that the lamp power gave impact to the heat 
radiation. The higher lamp power gave higher temperatre. We also found that over time, the temperature decreased because the lamp power began to weaken. The battery power used to turn on the lights begins to decrease. But, the results of the average temperature of each test tend to be stable.

We obtained that that Rice flour is prospective as a heat insulator. This is due to the lower temperature difference outside the box compared to the temperature inside the box. In testing using an 8 -W lamp, there is a temperature difference of $3.31^{\circ}$ between the points inside and outside the box. In testing using a 10-W lamp, there is a temperature difference of $2.09^{\circ} \mathrm{C}$ between the points inside and outside the box. In testing using a $12-\mathrm{W}$ lamp, there is a temperature difference of $5.62^{\circ} \mathrm{C}$ between the points inside and outside the box. The temperature outside the box which is $10 \mathrm{~cm}$ away is smaller than the $5 \mathrm{~cm}$ because the distance affects the heat radiation that occurs (Nandiyanto et al., 2020).

\section{CONCLUSION}

This study has been successfully investigated the use of rice flour as a heat insulator for learning media for students with special needs. Experiments were done method by testing rice flour placed on the wall that heat radiated by bulb lamp with various intensities (i.e. 8, 10 , and $12 \mathrm{~W})$. The results showed that rice flour is a good heat insulator. The concept of heat radiation and the change of heat adsorbed by rice flour was explained, which can be further developed for learning media for students with special needs. The rice flour caused the heat from the lamp inside the box to be restrained from spreading out completely. The concept of heat radiation and the change of heat adsorbed by rice flour was explained, which can be further developed for learning media for students with special needs. The results of this study are expected to facilitate teachers in providing understanding to students in understanding the occurrence of heat insulators, especially for students with special needs. 


\section{ACKNOWLEDGEMENT}

We would like to thank Universitas Pendidikan Indonesia for supporting this study. We acknowledged RISTEK BRIN (Grant: Penelitian Terapan Unggulan Perguruan Tinggi) and Bangdos Universitas Pendidikan Indonesia.

\section{REFERENCES}

Maryanti, R., Nandiyanto, A. B. D., Hufad, A., \& Sunardi, S. 2021. Science education for students with special needs in Indonesia: From definition, systematic review, education system, to curriculum. Indonesian Journal of Community and Special Needs Education, l(1): 1-8.

Nandiyanto, A. B. D., Raziqi, G. Y., Dallyono, R., \& Sumardi, K. 2020. Experimental demonstration for enhancing vocational students' comprehension on heat transfer through conduction and radiation of light bulb. Journal of Technical Education and Training, 12(3): 189-195.

Rosina, H., Virgantina, V., Ayyash, Y., Dwiyanti, V., \& Boonsong, S. 2021. Vocational education curriculum: Between vocational education and industrial needs. ASEAN Journal of Science and Engineering Education, 1(2): 105-110.

Soekoco, A. S. 2016. Serat insulator panas ramah lingkungan berbahan dasar recycled polypropylene dari limbah tutup botol air mineral. Journal of Industrial Research (Jurnal Riset Industri), 10(3), 142-146.

Syukur, M., \& Kusumastuti, E. 2015. Sintesis dan karakterisasi foamy geopolymer berbahan dasar abu layang batubara. Indonesian Journal of Chemical Science, 4(3): 189195. 